\title{
Living together, sometimes feeding in a similar way: the case of the syntopic hylid frogs Hypsiboas raniceps and Scinax acuminatus (Anura: Hylidae) in the Pantanal of Miranda, Mato Grosso do Sul State, Brazil
}

\author{
Sabagh, $L T .^{\text {a* }}{ }^{*}$ Ferreira, VL. ${ }^{\mathrm{b}}$ and Rocha, CFD. ${ }^{\mathrm{a}}$ \\ aLaboratório e Ecologia de Vertebrados, Departamento de Ecologia, Universidade do Estado do Rio de Janeiro - UERJ, \\ Rua São Francisco Xavier, 524, CEP 20550-019, Rio de Janeiro, RJ, Brasil

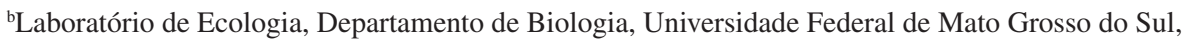 \\ Av. Costa e Silva, s/n, CP 549, CEP 79070-900, Campo Grande, MS, Brasil \\ *e-mail: leandro_sabagh@yahoo.com.br
}

Received July 14, 2009 - Accepted September 25, 2009 - Distributed November 30, 2010

\begin{abstract}
We studied the feeding ecology of two Hylinae anurans (Hypsiboas raniceps and Scinax acuminatus), living sympatrically and syntopically in the Pantanal of Miranda, Mato Grosso do Sul State, Brazil. The two hylid species had similar relative mouth width but differed in body size. The diet of the two frog species were composed of arthropodan prey. Both species consumed 11 different prey types, of which seven were common among them. Hypsiboas raniceps had a larger niche breadth $\left(\mathrm{B}_{\mathrm{A}}=0.64\right)$ than $S$. acuminatus $\left(\mathrm{B}_{\mathrm{A}}=0.48\right)$. Trophic niche overlap among frog species was $60.7 \%$. Our data are suggestive that although for many anurans the diet simply tend to reflect prey availability in the microhabitat, these two frog species, despite sharing similar microhabitat and period of activity (thus potentially exposed to a similar array of preys), tends to differ somewhat in diet (about 40\%) which may result from some intrinsic ecological aspects to each of them (e.g. ecophysiology) and/or differences in body size.
\end{abstract}

Keywords: diet, niche overlap, sympatric species, trophic niche.

\begin{abstract}
Vivendo juntos e algumas vezes alimentando-se de forma semelhante: o caso das pererecas sintópicas Hypsiboas raniceps e Scinax acuminatus (Anura: Hylidae) no Pantanal do Miranda, Mato Grosso do Sul, Brasil
\end{abstract}

\begin{abstract}
Resumo
Nós estudamos a ecologia trófica de duas espécies de anuros hilídeos (Hypsiboas raniceps e Scinax acuminatus), vivendo simpátrica e sintopicamente no Pantanal do Miranda, Mato Grosso do Sul, Brasil. As duas espécies possuíram largura da boca similar mas diferiram no tamanho do corpo. Ambas as espécies consumiram artrópodos, distribuídos em 11 diferentes tipos de presas das quais sete foram comuns entre elas. A amplitude do nicho trófico de $H$. raniceps $\left(\mathrm{B}_{\mathrm{A}}=0,64\right)$ foi relativamente superior aquela de $S$. acuminatus $\left(\mathrm{B}_{\mathrm{A}}=0,48\right)$. A sobreposição do nicho trófico entre as espécies foi de $60,7 \%$. Embora, para muitas espécies, a dieta tenda a refletir a disponibilidade de presas no microhabitat, nossos resultados sugerem que estas duas espécies de anuros, apesar de partilharem microhabitat e período de atividade (e, portanto, potencialmente estarem expostas ao mesmo universo de presas) tendem a diferir em algum grau nas suas dietas (cerca de 40\%) o que pode ser resultante de alguns aspectos ecológicos intrínsecos a cada uma delas (e.g. ecofisiologia) e/ou diferenças no tamanho corpóreo.
\end{abstract}

Palavras-chave: dieta, sobreposição de nicho, espécies simpátricas, nicho trófico.

\section{Introduction}

Syntopic related species are expected to be exposed to a similar array of potential prey, especially if they share activity period, body size and microhabitat features (e.g. Pianka, 1986; Sluys and Rocha, 1998; Guimarães and Bastos, 2003). This may result in considerable overlap of prey consumption, especially if they are closely related taxonomically and thus, also tend to share physiological and behavioural traits (see Menin et al., 2005). Therefore, a clear understanding of the relationship on niche overlap, similarity and competition among species is necessary to answer questions on community structure (Lawlor, 1980). 
Hypsiboas raniceps Cope, 1862 and Scinax acuminatus Cope, 1862 are sympatric and syntopic nocturnal arboreal hylid frogs (both Hylinae) common to open areas (De La Riva et al., 2000; Uetanabaro et al., 2008) of central and western Brazil, with males usually calling at the edge of semi-permanent or permanent ponds, flooded areas or shrubs (Prado et al., 2005; Uetanabaro et al., 2008). Both species share the same reproductive modes and have similar reproductive periods (Prado and Haddad, 2005; Prado et al., 2005), are tolerant to drought (Alho, 2008), ovipositing eggs from which develop exotrophic tadpoles (Prado and Haddad, 2005; Prado et al., 2005). Also, these species are reported to have apparently some similarities in body size (Prado et al., 2005).

At the Pantanal subregion of Miranda, in Corumbá municipality, Mato Grosso do Sul State these two species are found living sympatrically and syntopically. Considering the large set of similarities in ecological (microhabitat, main activity period, reproductive mode and period) and in morphological aspects (e.g. body size), we could expect that a considerable similarity in trophic niche should arise as a result of living in syntopy and sharing such ecological aspects.

In this study we analyse the trophic niche of $H$. raniceps and $S$. acuminatus living in syntopy at the Pantanal of Miranda, in central-western Brazil. Specifically we addressed the following questions: i) What is the diet composition of each frog species?; ii) Which are the main prey types consumed by each frog species?; iii) Which is the niche breadth of each species and the niche overlap among them; iv) Do the two species differ significantly in body size?

\section{Material and Methods}

\subsection{Study area}

The study was carried out at the subregion of the Pantanal called Miranda in Corumbá municipality, Mato Grosso do Sul State (MS) in the surroundings of the "Base de Estudos do Pantanal" of the Universidade Federal do Mato Grosso do Sul (UFMS) (57 ${ }^{\circ} 00^{\prime} \mathrm{W}, 19^{\circ} 34^{\prime} \mathrm{S}$ ). In the area, some formations of the Savannah arboreal vegetation predominate, with portions of semi-decidual forests, gallery forests and pastures (floodplain) being common elements of the landscape (Prado et al., 2002) fed by one of the largest rivers of the Pantanal, the Miranda river (Alho, 2008). Mean annual rainfall in the region is about $1,215 \mathrm{~mm}$ and annual temperature averages $25.1^{\circ} \mathrm{C}$ (Prado et al., 2005). For a comprehensive checklist of frog species of the region see Prado et al. (2005).

\subsection{Collecting methods and analysis}

Collections were made at night during September 2008 between 8:00 PM and 00:00 AM. Frogs were collected by hand, posteriorly anesthetised with xylocain and fixed in $10 \%$ formalin as soon as possible. The two species occurred simultaneously in the habitat and were not calling on collection nights.
For each individual frog we measured the snout-vent length (SVL), and mouth width (MW), to the nearest $0.1 \mathrm{~mm}$, using a Vernier Caliper. The frogs were dissected and their stomach contents analysed qualitatively and quantitatively under a stereomicroscope. Food items were identified, measured (to the nearest $0.1 \mathrm{~mm}$ ) and categorised to the taxonomic level of order. Unidentified arthropod remains were grouped in a separate category "unidentified parts of arthropods". Diet composition was estimated based on number, volume and frequency of occurrence (percentage of stomachs with a particular prey category) of each prey type in the stomachs. The length and width of each prey item were measured and its volume $(\mathrm{V})\left(\mathrm{in} \mathrm{mm}^{3}\right.$ ) estimated using the ellipsoid formula (Dunham, 1983). An index of relative importance (IRI) of each prey category in the diet was estimated second Pianka et al. (1971). Food niche breadth (based on the number of food items) was estimated using the formula proposed by Levins (1968). The values of niche breadth were standardized $\left(\mathrm{B}_{\mathrm{A}}\right)$ to a range of 0 to 1 using the appropriate formula. We used the Morisita-Horn index $\left(\mathrm{C}_{\mathrm{H}}\right)$ (Horn, 1966) to estimate the trophic niche overlap. This index value varies from 0 to 1 where 0 indicates absence of overlap and 1 indicates total overlap.

Differences among frog species in body size (SVL) were tested using a T-test and differences in relative mouth size were tested using an Analysis of Covariance (ANCOVA), in which frog SVL as a covariate (Zar, 1984). All measurements are presented as mean \pm 1 standard deviation and range. Prior to using each statistical test, we tested for the normality of the data distribution. When the data did not meet normality assumptions we used non-parametric statistics. We used the value of 0.05 as the cut-off for significance in all statistical tests.

\section{Results}

We sampled a total of 68 individual frogs (37 Hypsiboas raniceps and 31 Scinax acuminatus). Of these, four individuals of $H$. raniceps (10.8\%) and 11 of $S$. acuminatus (35.5\%) had empty stomachs. The mean SVL of H. raniceps $(44.8 \pm$ $6.3 \mathrm{~mm}$; range $=31.5-58.8 \mathrm{~mm}$ ) was significantly larger than that of $S$. acuminatus $(40.7 \pm 2.0 \mathrm{~mm}$; range $=35.5$ $45.0 \mathrm{~mm})\left(\mathrm{t}_{\mathrm{svl}}=3.449 ; \mathrm{df}=66 ; \mathrm{p}=0.001\right)$. However, the frog species did not differ in terms of relative $\mathrm{MW}($ H. raniceps $=$ $14.2 \pm 2.0 \mathrm{~mm} ; 10.3-19.2 \mathrm{~mm} ;$ S. acuminatus $=13.8 \pm$ $2.0 \mathrm{~mm}$; range $=11.2-19.6 \mathrm{~mm})\left(\right.$ ANCOVA: $\mathrm{F}_{1,33}=3.795$; $\mathrm{p}=0.06)$.

Both $H$. raniceps and $S$. acuminatus consumed 11 different prey types in their diet. The prey items shared by the two frog species were spiders, ants, dipterans, coleopterans, blatarians, orthopterans and hemipterans (Table 1) with some other prey types being consumed exclusively by one or other frog species.

In terms of number, the most representative items in the diet of $H$. raniceps were coleopterans $(22.5 \%)$ and blattarians $(20.0 \%)$ (Table 1$)$. In terms of volume, blattarians dominated $(54.2 \%)$ followed by coleopterans 
$(34.3 \%)$ (Table 1). The most frequent prey item in the diet of $H$. raniceps were coleopterans $(22.9 \%)$ and blattarians $(20.0 \%)$ (Table 1). On the other hand, numerically, the most common items in the diet of $S$. acuminatus were spiders $(32.0 \%)$ and orthopterans $(20.0 \%)$ (Table 1). Volumetrically blattarians dominated $(71.6 \%)$ followed by lepidopteran larvae $(7.1 \%)$. In terms of frequency, spiders $(40.0 \%)$ and orthopterans $(25.0 \%)$ were the most representative items. Coleopteran larvae were consumed only by $H$. raniceps whereas lepidopteran larvae were consumed exclusively by S. acuminatus (Table 1). Considering the estimated relative importance index (IRI), blattarians and coleopterans had greater importance in the $H$. raniceps diet whereas for $S$. acuminatus spiders and blattarians attained a higher IRI value (Table 1). Plant remains were found in eight stomachs (22.9\%) of H. raniceps and in two (10.0\%) of S. acuminatus. The mean number of preys in the stomach did not differ significantly among species ( $S$. acuminatus $=1.47 \pm$ 1.00 preys; $H$. raniceps $=2.05 \pm 1.27$ preys) (MannWhitney test: $U=206.50 ; p=0.1513)$. Mean prey length independent of frog body size did not differ significantly among species (ANCOVA, $F_{1,33}=0.366 \mathrm{p}=0.549$ ). Similarly, the studied species also did not differ in terms of mean volume of prey consumed (S. acuminatus $=49.8 \pm$ $115.3 \mathrm{~mm}^{3}$; H. raniceps $\left.=44.2 \pm 144.9 \mathrm{~mm}^{3}\right)$ (MannWhitney test: $\mathrm{U}=422.00 ; \mathrm{p}=0.8312)$. Trophic niche breadth for $H$. raniceps was $7.41\left(\mathrm{~B}_{\mathrm{A}}=0.64\right)$ whereas that for S. acuminatus was $5.84\left(\mathrm{~B}_{\mathrm{A}}=0.48\right)$. Trophic niche overlap among frog species was $60.7 \%$.

\section{Discussion}

Our data are suggestive that even living in syntopy, being relatively close taxonomically (same Subfamily), and potentially exposed to a similar prey spectrum, the hylids Scinax acuminatus and Hypsiboas raniceps differ in some aspects of their diet, with a niche dissimilarity of about $40 \%$. This number could result, in part from the identification level of prey as emphasised Menin et al. (2005). Although both species fed on similar number of prey types (both species $=11$ prey types), differences in terms of the quality of consumed prey potentially contributed to observed differences in the diets. For example, dipteran and lepidopteran larvae together with Dermaptera were preyed on exclusively by S. acuminatus, whereas coleopteran larvae, Odonata, Isopoda and Acari were consumed only by $H$. raniceps. Although for many anurans the diet simply tends to reflect prey availability in the microhabitat (Duellman and Trueb, 1994), our data on the diet of these two syntopic species (which are supposedly under similar prey spectrum) are suggestive that some ecological aspects intrinsic to each of them (e.g. ecophysiology) and/or size (the species differed in body size) tend to result in differences in types of prey consumed and in their frequencies.

The consumption of the prey items ingested by the two syntopic frogs are not unexpected since a diet composed by those arthropod preys are known also from the diet of other frog in the same area. Trachycephalus venulosus diet was exclusively composed by Coleoptera, Diptera, Hemiptera, Hymenoptera, Orthoptera, Pseudoescorpionida

Table 1. Diet composition of two anurans (Hypsiboas raniceps and Scinax acuminatus) living syntopically at the Pantanal of Miranda, MS - Brazil, with respective proportional values of prey consumption by number (\%N), by volume (\%V), by frequency $(\% \mathrm{~F})$, and the estimated index of relative importance (IRI).

\begin{tabular}{|c|c|c|c|c|c|c|c|c|}
\hline \multirow{2}{*}{ Items } & \multicolumn{4}{|c|}{ Hypsiboas raniceps $(\mathrm{n}=33)$} & \multicolumn{4}{|c|}{ Scinax acuminatus $(n=20)$} \\
\hline & $\% \mathbf{N}$ & $\% \mathrm{~V}$ & $\% \mathbf{F}$ & IRI & $\% \mathbf{N}$ & $\% \mathrm{~V}$ & $\% \mathbf{F}$ & IRI \\
\hline Acari & 5.00 & 0.01 & 5.71 & 28.61 & - & - & - & - \\
\hline Araneae & 12.50 & 0.95 & 14.29 & 192.20 & 32.00 & 4.26 & 40.00 & 1450.40 \\
\hline Hymenoptera (Formicidae) & 7.50 & 0.53 & 8.57 & 68.82 & 4.00 & 0.01 & 5.00 & 20.05 \\
\hline Diptera (Brachycera) & 7.50 & 0.93 & 5.71 & 48.14 & 4.00 & 0.75 & 5.00 & 23.75 \\
\hline Diptera Larvae & - & - & - & - & 4.00 & 1.70 & 5.00 & 28.50 \\
\hline Coleoptera & 22.50 & 34.29 & 22.86 & 1298.22 & 8.00 & 5.68 & 10.00 & 136.80 \\
\hline Coleoptera Larvae & 2.50 & 0.17 & 2.86 & 7.64 & - & - & - & - \\
\hline Lepidoptera Larvae & - & - & - & - & 4.00 & 7.10 & 5.00 & 55.50 \\
\hline Mecoptera & - & - & - & - & 8.00 & 0.44 & 5.00 & 42.20 \\
\hline Blattaria & 20.00 & 54.17 & 20.00 & 1483.40 & 8.00 & 71.56 & 10.00 & 795.60 \\
\hline Orthoptera & 5.00 & 1.46 & 5.71 & 36.89 & 20.00 & 5.17 & 25.00 & 629.25 \\
\hline Hemiptera & 7.50 & 2.60 & 8.57 & 86.56 & 4.00 & 1.41 & 5.00 & 27.05 \\
\hline Dermaptera & - & - & - & - & 4.00 & 1.92 & 5.00 & 29.60 \\
\hline Odonata & 2.50 & 0.28 & 2.86 & 7.95 & - & - & - & - \\
\hline Isopoda & 7.50 & 4.60 & 2.86 & 34.61 & - & - & - & - \\
\hline Plant remains & - & - & 22.86 & - & - & - & 10.00 & - \\
\hline Unidentified remains & - & - & 28.57 & - & - & - & 20.00 & - \\
\hline
\end{tabular}


and Araneae (Muri, 2005). For H. raniceps at another area, Rossa-Feres (1997) studying an anuran assemblage, recorded Coleoptera e Odonata for two adult $H$. raniceps resulting in a trophic niche breadth of 1.60 .

The few pieces of plant material we found in the stomachs of individual frogs corresponded to only fragments of dead leaves which suggested to us accidental ingestion during the prey capture. An accidental ingestion of plant material when capturing prey has been reported for some treefrog species (e.g. Oplinger, 1967; Rossa-Feres, 1997; Sluys and Rocha, 1998; Teixeira et al., 2002; Santos et al., 2004; Mahan and Johnson, 2007).

Our data indicated that the proportion of individuals having empty stomachs differed consistently among species (H. raniceps $=10.8 \%$ and $S$. acuminatus $=35.5 \%)$ which in turn may be suggestive that the two species may differ in their energy balance. The observed proportion of individuals of a species having empty stomachs has been used as an index of instantaneous energy balance for some organisms such as lizards (Huey et al., 2001), and fishes (Arrington et al., 2002). The idea is that individuals having empty stomachs are assumed to be in negative energy balance, depending on reserve stores (at least at that moment) provided by the incoming of previous feeding as source for metabolic processes and maintenance of energy needs (Boivin and Power, 1990; Huey et al., 2001; Arrington et al., 2002). Conversely, if individuals have food in their stomachs they will be gaining energy and thus, will be in positive energy balance (Huey et al., 2001). Although presently we still need to know to which extent these energy trends work among frogs, our data is suggestive that, comparatively, S. acuminatus is in lower energy balance compared with $H$. raniceps. Another plausible hypothesis regarding differences on proportions of empty stomachs may be that it arises from the differences in timing of feeding by the two treefrogs (Menin et al., 2005). In this study S. acuminatus apparently fed somewhat later than $H$. raniceps. However, the two hypotheses need to be tested.

We conclude that the diet of the two syntopic frog species studied are composed of arthropodan prey, and that despite sharing similar microhabitat and activity (thus potentially exposed to a similar array of prey), they tend to differ somewhat in diet (about 40\%) which may result from some intrinsic ecological aspects to each of them (e.g. ecophysiology), differences in timing of feeding and/ or differences in body size.

Acknowledgements - We thank F.I. Martins, M.D. Nunes, J.L.M. Sugai and V.V. Kuhnen for assistance in the field and G. Graciolli for helping with the identification of stomach contents. We are grateful to the BEP-UFMS and to the Ecologia do Pantanal Field course for logistic support and for the opportunity. The Coordenação de Aperfeiçoamento de Pessoal de Nível Superior (CAPES) and the PPGE-UFRJ provided financial support to L.T.S. C.F.D.R. received funds from the Fundação Carlos Chagas Filho de Amparo à Pesquisa do Estado do Rio de Janeiro - FAPERJ through the "Programa Cientistas do Nosso Estado" (Process E-26/100.471.2007) and from the Conselho Nacional do Desenvolvimento Científico e Tecnológico - CNPq (Processes No. 477715/2006-0 and
307653/2003-0). D. Vrcibradic kindly revised the manuscript offering helpful suggestions. We thank the Instituto Chico Mendes for the permit for collection (Permit \#.18856-1).

\section{References}

ALHO, CJR., 2008. Biodiversity of the Pantanal: response to seasonal flooding regime and to environmental degradation. Brazilian Journal of Biology, vol. 68, Suppl. 4, p. 957-966.

ARRINGTON, DA., WINEMILLER, KO., LOFTUS, WF. and AKIN, S., 2002. How often do fishes "run on empty"? Ecology, vol. 83 , no. 8 , p. $2145-2151$.

BOIVIN, TG. and POWER, G., 1990. Winter condition and proximate composition of anodromous artic charr (Salvelinus alpinus) in eastern UngavaBay, Quebec. Canadian Journal of Zoology, vol. 68, p. 2284-2289.

DE LA RIVA, I., KÖHLER, J., LÖTTERS, S. and REICHLE, S., 2000. Ten years of research on Bolivian amphibians: updated checklist, distribution, taxonomic problems, literature and iconography. Revista Española de Herpetologia, vol. 14, p. 19-164.

DUELLMAN, WE. and TRUEB, L., 1994. Biology of Amphibians. Baltimore: The Johns Hopkins Press, 670 p.

DUNHAM, AE., 1983. Realized niche overlap, resource abundance, and intensity of interspecific competition. In PIANKA, RB. and SCHOENER, T. (Eds.). Lizard Ecology: studies of a model organism. Cambridge: Harvard University Press. p. 261-280.

GUIMARAES, LDA. and BASTOS, RP., 2003. Vocalizações e interações acústicas em Hyla raniceps (Anura, Hylidae) durante a atividade reprodutiva. Iheringia, Série Zoológica, vol. 93, no. 2, p. 149-158.

HORN, HS., 1966. Measurement of overlap in comparative ecological studies. The American Naturalist, vol. 100, p. 419-424.

HUEY, RB., PIANKA, ER. and VITT, LJ., 2001. How often do lizards "run on empty"? Ecology, vol. 82, no. 1, p. 1-7.

LAWLOR, LR., 1980. Overlap, similarity and competition coefficients. Ecology, vol. 61, no. 2, p. 245-251.

LEVINS, R., 1968. Evolution in changing environments: some theoretical explorations. Princeton: Princeton University Press, $132 \mathrm{p}$.

MAHAN, RD. and JOHNSON, JR., 2007. Diet of the Gray Treefrog (Hyla versicolor) in Relation to Foraging site location. Journal of Herpetology, vol. 41, no. 1, p. 16-23

MENIN, M., ROSSA-FERES, DC. and GIARETTA, AA., 2005. Resource use and coexistence of two syntopic hylid frogs (Anura, Hylidae). Revista Brasileira de Zoologia, vol. 22, no. 1, p. 61-72.

MURI, AF., 2005. Dieta de Trachycephalus venulosus (Laurenti 1768) (Amphibia: Anura: Hylidae) em uma Região do Pantanal Miranda/Abobral - MS. In LIMA, TN., DUTRA, PF., FRISON, S., ARAÚJO, AC., FISCHER, EA., GRACIOLLI, G. and RAIZER, J. (Eds.). Ecologia do Pantanal: curso de campo 2005. Campo Grande, Mato Grosso do Sul: Editora UFMS, p. 199-204.

OPLINGER, CS., 1967. Food habits and feeding activity of recently transformed and adult Hyla crucifer Wied. Herpetology, vol. 23 , no. 3, p. 209-217.

PIANKA, ER., 1986. Ecology and natural history of desert lizards. Princeton: Princeton University Press. 
PIANKA, L., OLIPHANT, MS. and IVERSON, ZL., 1971. Food habits of albacore bluefin, tuna and bonito in California waters. California Department of Fish and Game Bulletin, vol. 152, p. $1-350$.

PRADO, CPA. and HADDAD, CFB., 2005. Size-fecundity relationships and reproductive investment in female frogs in the Pantanal, south-western Brazil. Herpetolocical Journal, vol. 15, p. 181-189.

PRADO, CPA., UETANABARO, M. and HADDAD, CFB., 2002. Description of a New Reproductive Mode in Leptodactylus (Anura, Leptodactylidae), with a Review of the Reproductive Specialization toward Terrestriality in the Genus. Copeia, no. 4, p. 1128-1133.

PRADO, CPA., UETANABARO, M. and HADDAD, CFB., 2005. Breeding activity patterns, reprodutive modes, and habitat use by anurans (Amphibia) in a seasonal environment in the Pantanal, Brazil. Amphibia-Reptilia, vol. 26, p. 211-221.

ROSSA-FERES, DC., 1997. Ecologia de uma comunidade de anfibios anuros da região Noroeste do estado de São Paulo: microhabitat, sazonalidade, dieta e nicho multidimensional. Rio Claro: Universidade Estadual Paulista, 178 p. [Ph.D. Dissertation].
SANTOS, EM., ALMEIDA, AV. and VASCONCELOS, SD., 2004. Feeding habits of six anuran (Amphibia: Anura) species in a rainforest in Northeastern Brazil. Iheringia, Série Zoológica, vol. 94 , no. 4 , p. $433-438$.

SLUYS, M. van. and ROCHA, CFD., 1998. Feeding babits and microhabitat utilization by two syntopic Brazilian Amazonian Frogs (Hyla minuta and Pseudopaludicula sp. (gr. falcipes). Revista Brasileira de Biologia = Brazilian. Journal of Biology, vol. 58 , no. 4 , p. 559-562.

TEIXEIRA, RL., SCHINEIDER, JAP. and ALMEIDA, GI., 2002. The occurrence of amphibians in bromeliads from a Southeastern Brazilian Restinga habitat, whit special reference to Aparasphenodon brunoi (Anura, Hylidae). Brazilian. Journal of Biology, vol. 62, no. 2, p. 263-268.

UETANABARO, M., PRADO, CPA., RODRIGUES, DJ., GORDO, M. and CAMPOS Z., 2008. Guia de Campo dos Anuros do Pantanal Sul e Planaltos de Entorno/Field Guide to the Anurans of the South Pantanal and Surrounding Cerrados. Campo Grande: Editora UFMS, 96 p.

ZAR, JH., 1984. Biostatistical Analysis. 2 ed. New Jersey: Prendice Hall. 718 p. 
